\title{
Female urinary incontinence: a systematic overview and non-surgical treatment
}

\author{
Cosette Ngarambe, Dan-hong Peng*
}

Department of Gynecology \& Obstetrics, Zhongda Hospital the Affiliated Hospital of Southeast University, 87\# Ding Jia Qiao, Jiangsu Nanjing-210009, P.R. China

Received: 18 March 2015

Accepted: 19 April 2015

\author{
*Correspondence: \\ Dr. Dan-hong Peng, \\ E-mail: pdh-seu@ hotmail.com
}

Copyright: ( ) the author(s), publisher and licensee Medip Academy. This is an open-access article distributed under the terms of the Creative Commons Attribution Non-Commercial License, which permits unrestricted non-commercial use, distribution, and reproduction in any medium, provided the original work is properly cited.

\begin{abstract}
Urinary Incontinence was acknowledged in 1998 by World Health Organization as a disease, to raise the awareness of the condition. Literature suggests that $50 \%$ of the incontinent women would be less than 50 years of age. Despite the great evolution in the area of gynecology, incontinence remains a real problem for number of women around the world. In some area the embarrassing nature of urinary incontinence has lead women to hide the existence of syndromes. Most of the women will seek health care at a late stage, when there is little or nothing to do. Alternative opportunity of surgery reveal to be a costly choice as popular believes that urinary incontinence is a fatality to all women. Little is known or rather little is provided to women in order to understand the process which causes urinary incontinence, whereas to the shame inflicted to them. This review paper aims to give a systematic overview of female urinary incontinence, and to a certain extent to present its non-surgical approach.
\end{abstract}

Keywords: Urinary incontinence, Obstetric fistula, Non-surgical treatment, Pharmacotherapy

\section{INTRODUCTION}

Urinary incontinence is common in women, but is underreported and under treated. Despite the great work of awareness of Urinary Incontinence (UI) by the World Health Organization (WHO), popular belief is still an essential problem to providing care to the numerous women suffering of urinary incontinence. UI is more prevalent than most chronic diseases yet largely underreported. In a study conducted in sub-Sahara region, 77\% of patients with UI would not seek medical care, ${ }^{1}$ same results were found in another study in Taiwan where only an average of $29 \%$ of women seeking medical advice on UI. $^{2}$ In Majorca (Spain), 1 woman out of 4 suffers from UI and would seek medical care when quality of life has decreased, highlighting the severity of the condition. ${ }^{3}$ Kinchen et al. had come to the same conclusion earlier in their study, which is the sad reflection of UI reality. ${ }^{4}$ Many women suffer in silence, ${ }^{5}$ believing that it is a normal aging process, however research reported countless situation related to leak of urine.

\section{METHODOLOGY}

A computerized literature search was performed to identify all published articles on the subject. The following databases: PubMed (Medline), Highwire, Google Scholar, Scopus, Cochrane Database of Systematic Reviews and Cochrane Library were used. The search strategy involved entry of the word "urinary incontinence" with a combination of other words such as, "classification", "assessment", "obstretic fistula", "physiotherapy", "pharmacotherapy", "complementary alternative treatment", "non-surgical treatment", and "female" or "women". English-language full publications and English published abstracts (case reports, prospective study, clinical trials and scientific guidelines) were 
reviewed. The data were extracted and presented here in an optic to review this subject.

\section{DEFINITION}

According to International Continence Society (ICS), urinary incontinence is a storage symptom and defined as the complaint of any involuntary loss of urine even if the leak does not cause a social or hygienic problem. ${ }^{6} \mathrm{UI}$ is a common symptom that can affect women of all ages, with a wide range of severity and nature. While rarely lifethreatening, incontinence may seriously influence the physical, psychological and social wellbeing of affected individuals. The impact on the families and carers of women with UI may be profound, and the resource implications for the health service considerable. ${ }^{7}$

\section{PREVALENCE AND CLASSIFICATION}

Female urinary incontinence differs greatly between less developed and more developed countries. Even after taking into account differences in definitions, epidemiology methodology and demographic characteristics, there exists a large variation in the estimated prevalence of UI. ${ }^{8-12}$ The involuntary loss of urine has a prevalence of approximately $25 \%$ in young women (aged 14 to 21 years), ${ }^{13} 44 \%$ to $57 \%$ in middleaged and postmenopausal women (aged 40 to 60 years), ${ }^{14}$ and $75 \%$ in elderly women (aged $\geq 75$ years). ${ }^{15}$ However, these statistics may be underestimated due to the fact that at least half of incontinent women do not report the issue to their physicians as revealed some studies. ${ }^{16,17}$

With the complexity and difficulties to identify with accuracy urinary incontinence; terms such as Lower Urinary Tract Symptoms (LUTS) try to designate both urinary urgency and overactive bladder. In the past years,
3 important definitions have served to identify urinary Incontinence: Stress Urinary Incontinence (SUI), Urge Urinary Incontinence (UUI) and Mixed Urinary Incontinence (MUI). The ICS has published several new symptoms categories - nocturnal enuresis (the complaint of loss of urine during sleep); continuous urinary incontinence (the complaint of continuous leakage, classically associated with a fistula or urethral diverticulum); situational incontinence may be reported, e.g. giggle incontinence. ${ }^{18}$ Moreover, incontinence in the elderly has been categorised individually as acute or chronic. ${ }^{19}$ Known as "transient" incontinence, it is relatively common in the elderly, affecting up to onethird of community-dwelling elderly population and up to $50 \%$ of inpatients. ${ }^{20,21}$ Another type of incontinence known as "functional incontinence" includes cases of urinary incontinence where no organic cause can be found by which implying that urinary tract function is normal whereas research shows that normal urinary tract function is the exception, even in continent subjects, and is rare in incontinent. ${ }^{18,21}$ There is also an uncharacterized phenomenon of UI diagnosed in children. This type of UI is called "Phantom" Urinary Incontinence (PUI). In this condition, children with lower urinary tract symptoms and constipation feel the sensation of wetness because of presumed urinary incontinence despite being completely dry. ${ }^{22}$ Most children presenting with this condition had a prior diagnosis of Obsessive-Compulsive Disorder (OCD) or OCD traits as reported by parents.

The prevalence of UI by type in female incontinence is represented approximately as follows: SUI (50\%), MUI $(32 \%)$, UUI (14\%) and the remaining $4 \%$ represent other types of incontinence. ${ }^{23}$ However, what we know about UI are conclusions obtained from studies and observations on late stage of the condition. ${ }^{24}$ ICS has set a crucial distinction on the UI condition, symptoms, signs and urodynamic diagnosis which are shown in Table $1 .^{24}$

Table 1: Terminology for urinary incontinence.

\begin{tabular}{|c|c|c|c|}
\hline & Symptom & Sign & Urodynamic diagnosis \\
\hline $\begin{array}{l}\text { Stress urinary } \\
\text { Incontinence }\end{array}$ & $\begin{array}{l}\text { Involuntary loss of urine, with } \\
\text { effort or exertion, or on sneezing } \\
\text { or coughing. }\end{array}$ & $\begin{array}{l}\text { Involuntary leakage from the } \\
\text { urethra, with exertion or } \\
\text { effort, or on sneezing or } \\
\text { coughing. }\end{array}$ & $\begin{array}{l}\text { Involuntary leakage of urine shown during } \\
\text { raised abdominal pressure, in the absence } \\
\text { of a detrusor contraction is referred to as } \\
\text { urodynamic stress incontinence. }\end{array}$ \\
\hline $\begin{array}{l}\text { Bladder neck } \\
\text { hypermobility }\end{array}$ & $\begin{array}{l}\text { Involuntary loss of urine, with } \\
\text { effort or exertion, or on sneezing } \\
\text { or coughing. }\end{array}$ & $\begin{array}{l}\text { Hypermobile bladder neck on } \\
\text { Q-tip* or other objective } \\
\text { measure. }\end{array}$ & $\begin{array}{l}\text { High valsalva leak point pressure or high } \\
\text { maximum urethral closure pressures. }\end{array}$ \\
\hline $\begin{array}{l}\text { Intrinsic sphincter } \\
\text { deficiency }\end{array}$ & $\begin{array}{l}\text { Involuntary loss of urine, with } \\
\text { effort or exertion, or on sneezing } \\
\text { or coughing. }\end{array}$ & $\begin{array}{l}\text { Bladder neck could be raised } \\
\text { or hypermobile. }\end{array}$ & $\begin{array}{l}\text { Low valsalva leak point pressure or low } \\
\text { maximum urethral closure pressure. }\end{array}$ \\
\hline $\begin{array}{l}\text { Urge Urinary } \\
\text { Incontinence }\end{array}$ & $\begin{array}{l}\text { Involuntary leakage } \\
\text { accompanied by or immediately } \\
\text { preceded by urgency }\end{array}$ & $\begin{array}{l}\text { Urine leakage seen during } \\
\text { examination from the urethra } \\
\text { associated with urgency. }\end{array}$ & $\begin{array}{l}\text { Incontinence due to an involuntary detrusor } \\
\text { contraction, usually with a sensation of } \\
\text { urge, is known as detrusor over-activity } \\
\text { Incontinence. }\end{array}$ \\
\hline
\end{tabular}




\section{MECHANISM AND PATHOPHYSIOLOGY}

The complex anatomy of the urinary tract is such in a way that it regulates and harmonizes the moves of the urinary tract maintaining the continence. Coming to understand the anatomy and physiology of the urinary track and pelvic floor is the enigma of UI, which allows a better understanding of each type of urinary incontinence. ${ }^{25}$ The bladder is a hollow muscular that is sited on the pelvic floor. The detrusor is the main muscle of the bladder made of smooth muscles, which maintain the bladder for any unnecessary movements. There are also urinary sphincters (urethral sphincter) a group of muscles that contract around the urethra in order to maintain bladder control. These muscles can be categorized in two. The first one known as internal sphincter seems to be less developed in female, it is a muscle that is contracted at every moment except during voiding (urination), but it relaxes during voiding. The second one known as external sphincter is contracted the whole time, when bladder is full to avoid involuntary leak of urine.

These 2 kinds of muscles work like water tap, they are most of time contracted (closed), and they relax and open when voiding, to allow the urine to be evacuate. When there is a feeling of bladder fullness and need for voiding, a sensorial message is sent from the brain to the sphincter, giving them signal to relax, which will resolve to urination. In the other hand detrusor which is the most important muscle of bladder, remains relaxed to allow the bladder to store urine. When signal from the brain is given, detrusor contracts in a squeezing movement to allow the urine to descend from bladder to urethra. ${ }^{25}$

\section{CAUSES AND RISK FACTORS}

According to De Lancet 2006, UI is simply caused by dysfunction in the storage of Urine, especially in the emptying process of the lower urinary tract. ${ }^{26}$ The etiology of UI is still poorly understood, but various scientific papers present UI as inevitable result of aging, causing changes in urine flow due to the aging of tissues and neurologic connections. For women, the aging process induces imbalance or deficiency of hormones that cause the mucosal tissues to become weak. ${ }^{27}$

Mode of delivery and parity is considered as factors contributing towards worsening of urinary incontinence. $^{28-31}$ It is well known that the vaginal delivery generates neurologic changes that affect the Urethra; these changes seem to be less pronounced in cases of caesarian section (C/section), ${ }^{32,33}$ giving c/section a protective role against UI. A Chinese study ${ }^{34}$ on primipara who delivered either vaginal way or by c/section concluded a high occurrence of UI in the vaginal birth group than in the Caesarian section group; it also suggested that vaginal delivery, lateral episiotomy and new born weight (over $4000 \mathrm{~g}$ ) were risk factor of postpartum UI and pelvic Organ prolapse. Questions remain about the protective role of $\mathrm{C} /$ section as a selective option or after experiencing contractions.

Mallett and colleagues refuted that multiparity was a risk factor for UI, showing that neurologic changes that lead to UI would be occurring at the first vaginal delivery. ${ }^{35}$ Would then UTI be a risk for UI? The drop of estrogen in peri-menopause and menopause would be able to cause weaken of the urethra, assertion that the European Association of urology disagrees with, in its 2009 guidelines for UI: "menopause per se does not appear to be a risk factor for UI and there is conflicting evidence regarding hysterectomy". ${ }^{2}$ The 2013 UI guidelines for UI suggested that there were no evidence Urinary Tract Infections (UTI) causes UI or that treating UTI would improve UI. ${ }^{7}$ Women weight is considerable as a potential risk factor of urinary incontinence. ${ }^{36,37} \mathrm{~A}$ Spanish review reported similar findings of weight loss after pregnancy or retained BMI during pregnancy, by which have had important impacts on prevalence of UI. Women who undergo weight loss were found to improve the condition of their UI. ${ }^{38}$

Alcohol and medication use are also causes and risk factors of UI. In the elderly, they are major causes of acute incontinence. Polypharmacy and the use of psychotropic medication compound problems with incontinence, and are most prevalent in women aged 85 years or over and appear to be increasing. ${ }^{18}$ Medications including diuretics (e.g.: Frusemide), anticholinergics (e.g.: Antihistamine), narcotic analgesia (e.g.: Opioids), $\alpha$-blockers (e.g.: Prazosin), $\mathrm{Ca}^{2+}$-channels blockers (e.g.: Nifedipine), prostaglandins (e.g.: Misoprostol) may aggravate or predispose to UI. ${ }^{18}$

\section{FISTULAE IN THE DEVELOPING WORLD}

Obstetrical fistulae is defined as defect in the genital tract connecting the vaginal or uterine cavity to the bladder (vesicovaginal fistula), urethra, erecters, rectum or colon (rectovaginal fistula) caused by obstructed birth canal or a too long labor. ${ }^{39}$ The most direct consequence/complication of fistulae is the constant leaking of Urine, which leads major of time to kidney disorders, skin infections, and death for unattended cases.

In Western society, urogenital/rectal fistulas are mostly caused by radiotherapy and/or surgery ${ }^{40,41}$ However, in the developing countries, obstetric fistulae are common. ${ }^{42}$ Estimates indicate that 2-3 millions women live with obstetric fistulae worldwide, the majority of whom are in Africa and Asia. ${ }^{43-45}$ Fistulas are preventable and treatable, however, many women are still unaware of the availability of treatment and $80 \%$ of them never seek treatment due to lack of knowledge. ${ }^{43}$ Moreover, women suffering from this condition are initially kept hidden; subsequently, they find it difficult to maintain decent standards of personal hygiene because water for washing is generally scarce; divorce becomes inevitable and 
destitution follows, these women being forced to beg for their livelihood. ${ }^{46}$

Despite much debate, there is no universally accepted system for classifying fistulae, and a wide variety of different systems have been proposed [including Marion Sims (1852), McConnachie (1958), Lawson (1968), Goh (2004), WHO (2006) and Arrowsmith (2007)]. ${ }^{47}$ Classification of fistulas is important only to the extent that the classification has a meaningful relationship to the prognosis of the injury. However, most surgeons base their classification on simple descriptive terms involving three factors: site, size and scarring. ${ }^{48}$ Based on the WHO, Fistulae can be categorized as simple fistula (good prognosis/simple) and complex fistula (larger than $3 \mathrm{~cm}$, complicated/uncertain prognosis). ${ }^{47}$

\section{ASSESSMENT OF INCONTINENCE}

Not all kinds of UI necessitate special treatment; initial assessment will be able to reveal which case is complicate and needs to be referring to a specialist. The obstetric and gynecological history is the first steps in assessing any patients suspected with UI, throughout the history the patient will be asked questions that will lead the care provider to categorize the kind of UI, timing, severity or association with other conditions. Patients with pain, recurrent Urinary tract Infections, hematuria, Pelvic Organ Prolapse, fistula, previous pelvic surgery and radiotherapy are called "complicated incontinence group". 12

Questionnaire such as ICIQ-UI (International Consultation on Incontinence Questionnaire - Urinary Incontinence), ISI (Incontinence Stress Index), RUIS (Revised Urinary Incontinence scale), LSA (Life space assessment), UDI-6 (Urogenital Distress Inventory), EPI (Estimated Percent Improvement) and PSQ (Patient Satisfaction Question) are tools often used to understand the patient's symptoms and to assess her quality of life (QoL). ${ }^{49}$

\section{URODYNAMIC ASSESSMENT AND PHYSICAL EXAM}

The term 'urodynamics' encompasses a number of varied physiological tests, of bladder and urethral function, which aim to demonstrate an underlying abnormality of storage or voiding. ${ }^{7}$ An urodynamic assessment must interpret urodynamic findings in relation to the clinical picture and symptoms taking into consideration Frequency-volume chart, Pad testing, Flow rate, ultrasound, conventional cystometry and videocystometry as key tests. ${ }^{50}$ The Figure 1 shows a convential cystometrogram of an incontinent patient. In this test, the detrusor overactivity is apparent on filling and after coughing (the pressure spikens on $\mathrm{P}_{\mathrm{abd}}$ and $\mathrm{P}_{\mathrm{ves}}$ ). Increasing overactivity occurs on filling until the patient voids off an overactive contaction. The rate if filling is 90 $\mathrm{ml} /$ minute. ${ }^{50}$ Moreover, other than urodynamics studies, tests such as the Q-tip, POP-Q, Bonney, Marshall and Fluid-Bridge can assess urethral competence, in terms of hypermobility of the urethrovesical junction. ${ }^{7}$

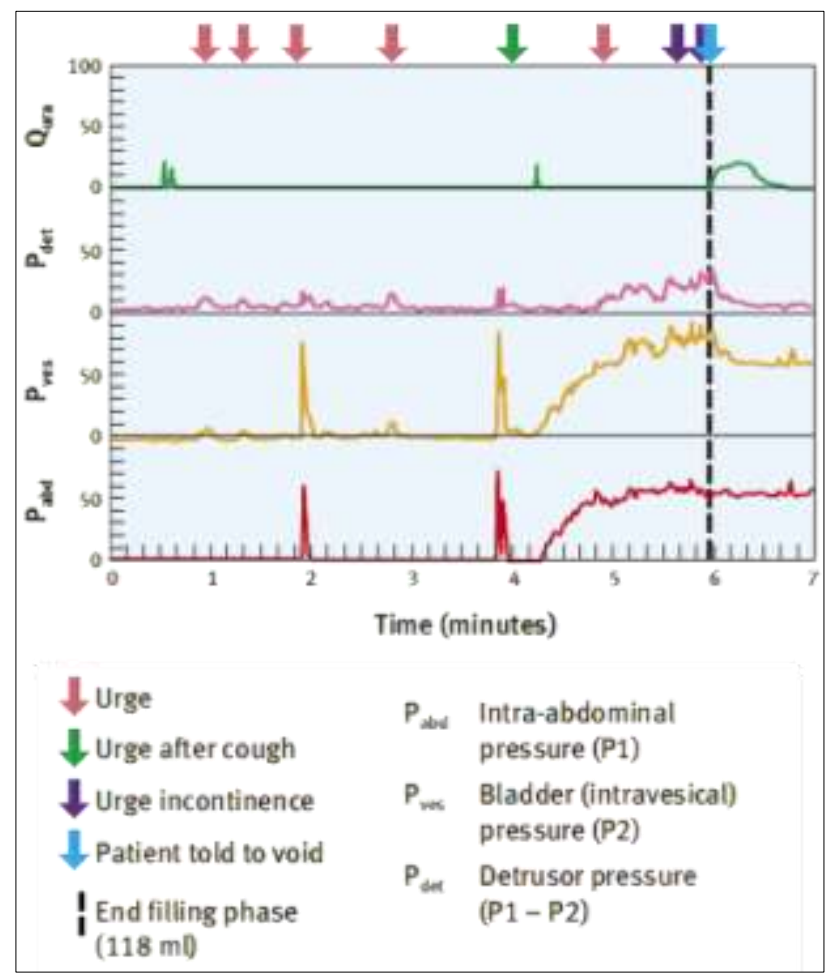

Figure 1: Cystometrogram trace from an incontinent patient. $^{50}$

\section{THE MANAGEMENT AND TREATMENT OF URINARY INCONTINENCE}

After a throughout evaluation of the condition, treatment will depend on the type of UI and the severity of the symptoms. Management should be taken into 2 phases: an initial management which consists basically on change of lifestyle, reeducation also called conservative treatment and use of drugs; specialized management is the next step for UI which failed Initial treatment, or for very complicated case of UI.

Healthy elderly persons should be offered a similar range of treatment options as younger persons. However, frail/elderly persons, require a different approach. Their evaluation must address the potential role of comorbidity, current medications (prescribed, over-thecounter, and/or naturopathic), and functional and/or cognitive impairment for the management of UI. The management should take into consideration the degree of bother to the patient and/or carer, their goals for care, level of co-operation, and the overall prognosis and life expectancy. ${ }^{12}$

The Figures 2-5 present the various algorithms in assessment of incontinence in terms of management recommendations. 


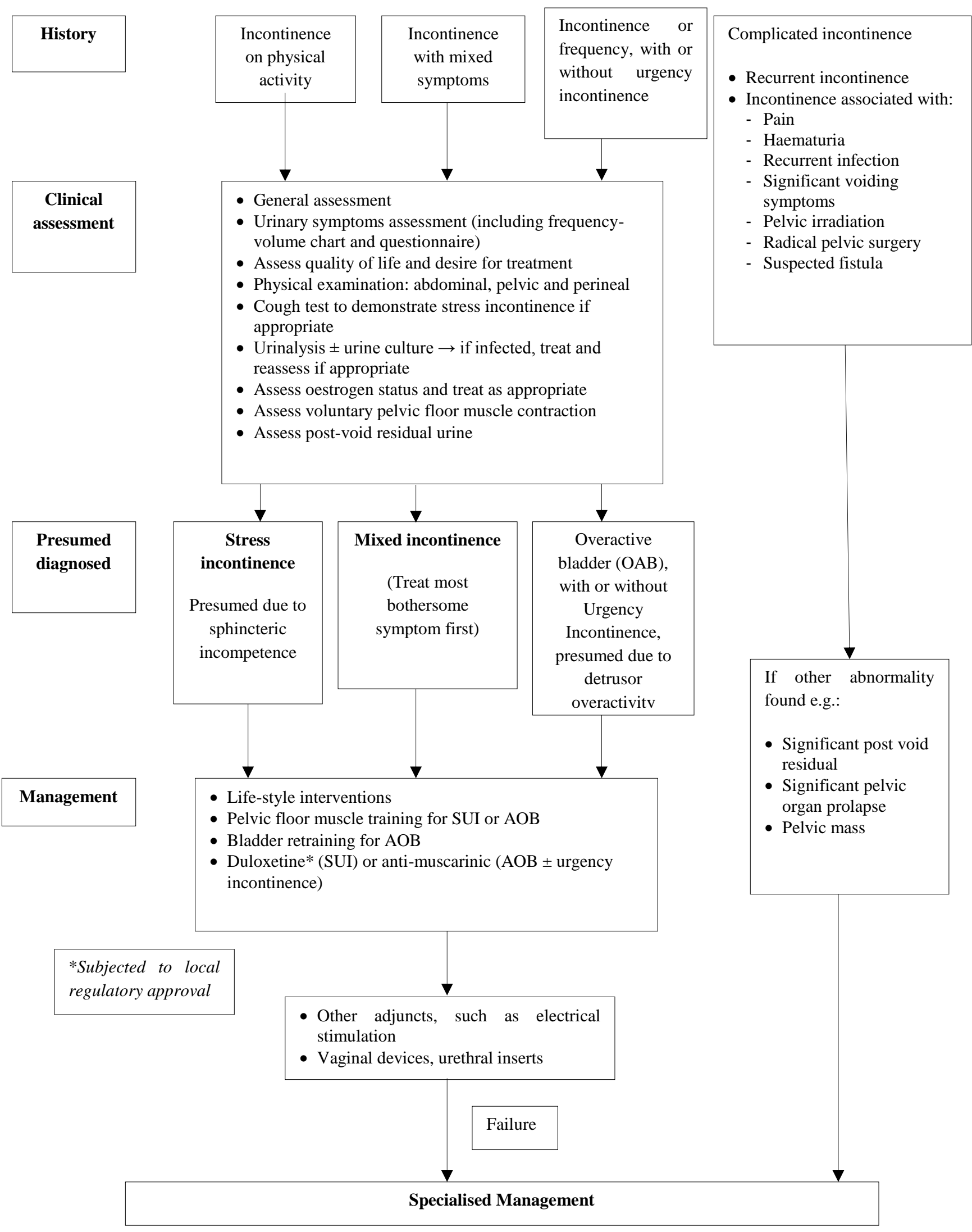

Figure 2: Algorithm of initial management of UI. ${ }^{12}$ 


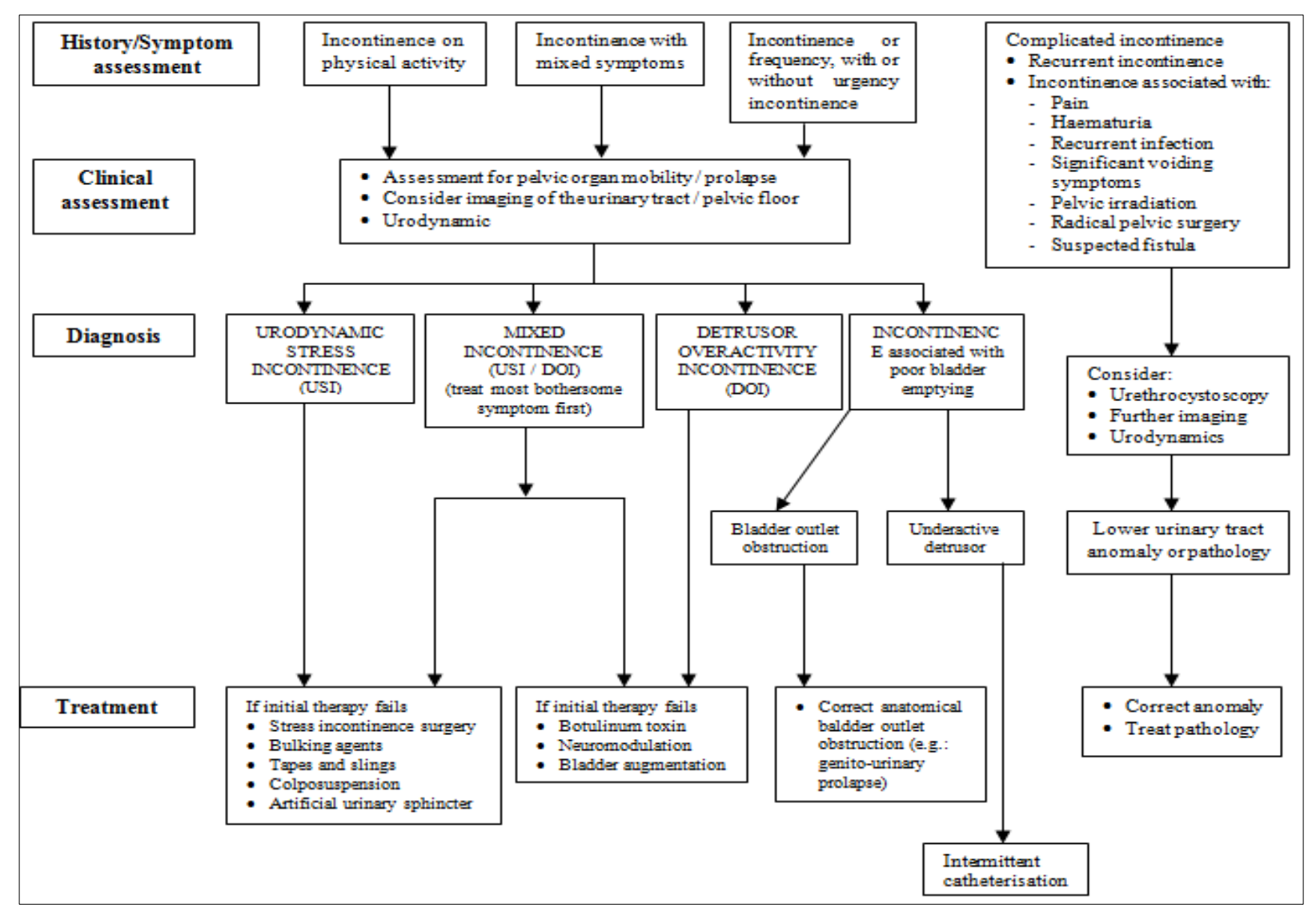

Figure 3: Algorithm of specialised management of UI. ${ }^{12}$

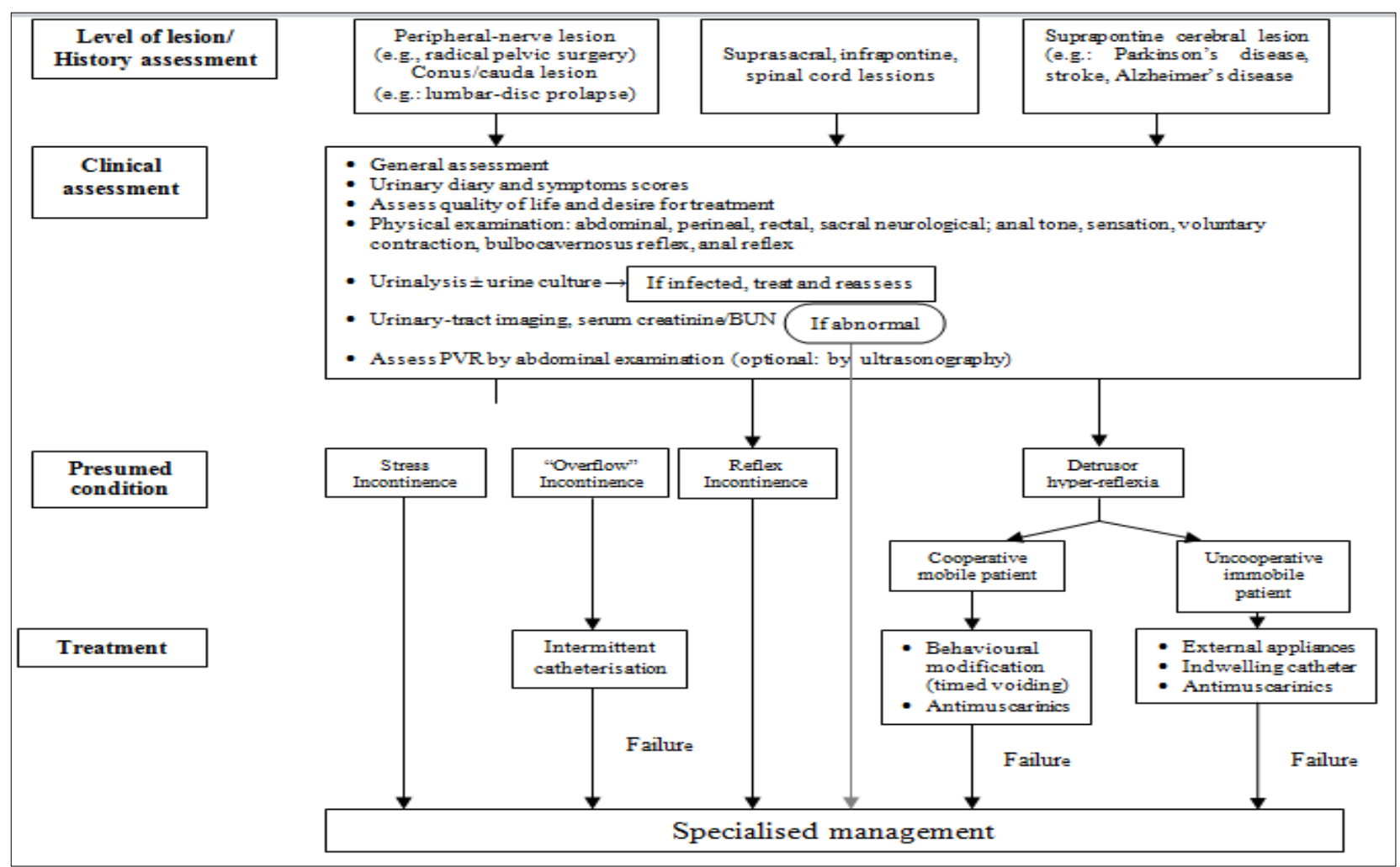

Figure 4: Algorithm of initial management of neurogenic urinary incontinence. ${ }^{51}$

Note: $\mathrm{BUN}=$ Blood urea nitrogen, $\mathrm{PVR}=$ Post-void residual 


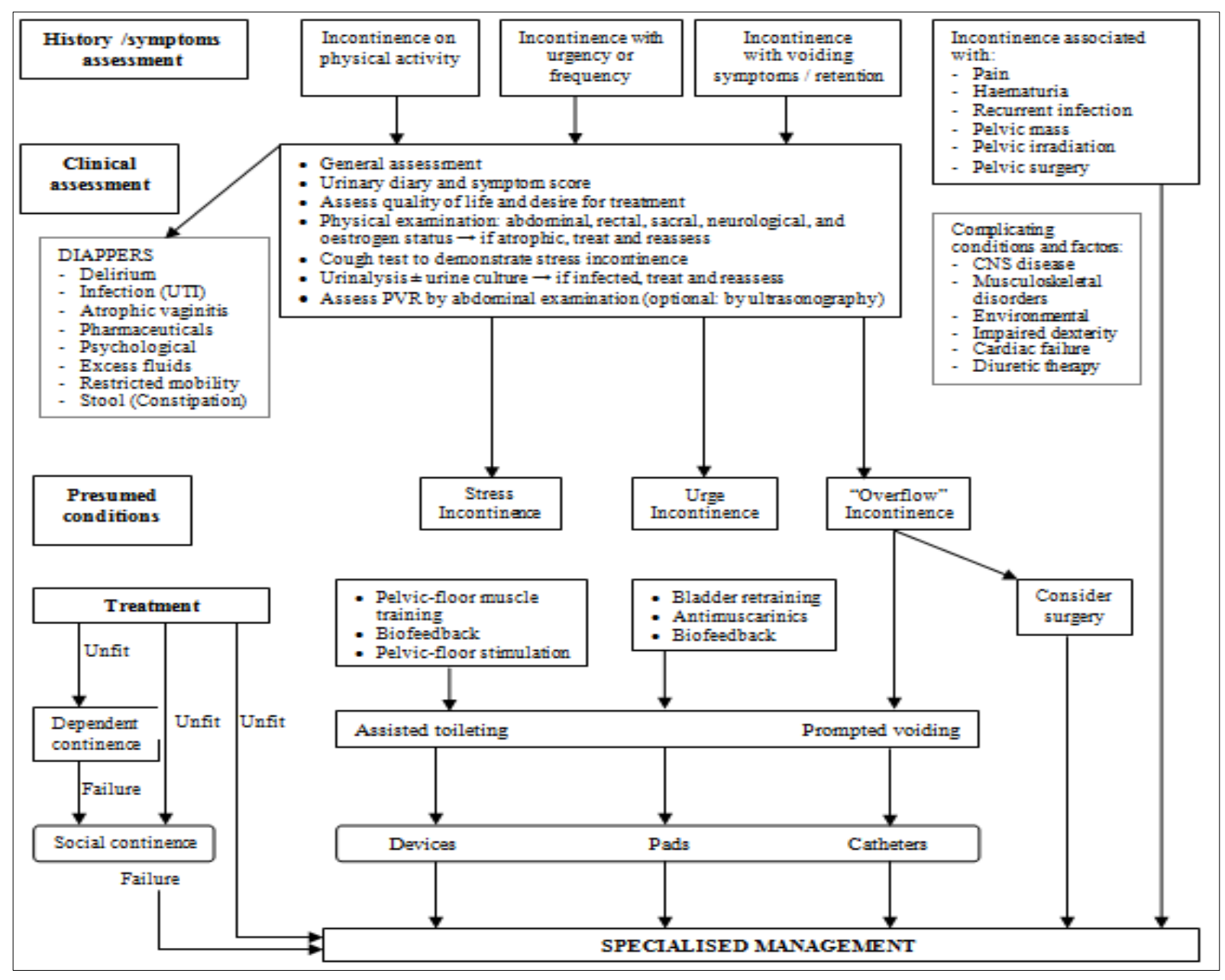

Figure 5: Algorithm of initial management of UI in frail disabled elderly people. ${ }^{51}$

UTI = Urinary tract infection; $\mathrm{CNS}=$ Central nervous system; ADL = Activities of daily living; PVR = Post-void residual

\section{CONSERVATIVE TREATMENT}

Defined by the ICS, 'Conservative treatment' is a group of therapies that are usually low cost, and managed principally by the person with UI with instruction/supervision from a healthcare professional. These include lifestyle interventions, physical, behavioural, drug and complementary therapies, and nontherapeutic interventions (such as products that collect or contain leakage). ${ }^{7}$

\section{Lifestyle interventions}

Various observational studies have considered the possible association between lifestyle factors and UI, many of which include both men and women, investigating how lifestyle factors may affect the prevalence, or incidence, of UI or OAB were considered. These factors include bowel habit, dietary factors, caffeine, fluid intake, smoking, weight and physical exercise. ${ }^{7}$ Mounting data of observational studies and few clinical trials have addressed the evidence impact for lifestyle interventions. ${ }^{52-55}$

\section{Physiotherapy}

Physiotherapists have become involved in the clinical management of UI in women, as the presumptive underlying impairments (i.e., decreased pelvic floor muscle strength and/or endurance, decreased awareness of bladder irritants) fall within the scope of physiotherapy practice according to the Guide to Physical Therapist Practice. ${ }^{56}$ Pelvic floor muscle training (PFMT, also known as Kegel Exercises), vaginal cones, neurostimulation, biofeedback, magnetic therapy and electrical stimulation are varieties of physical therapies used in the management of female UI. ${ }^{57-61}$

\section{Behavioural therapies}

Behavioural therapy involves individual learning new patterns of response or re-establishing previously learnt 
behaviour to fit in with what is considered usual. Women with OAB (wet or dry) usually void more frequently than usual due to urgency. Women with stress UI also often void more frequently in the belief that they will pre-empt an involuntary urine loss associated with any increase in intra-abdominal pressure. ${ }^{7}$ Bladder training and toileting programmes (prompted voiding and timed voiding) are various behavioural therapies usually used. All these therapies appear to show improvements in leakage episodes. $^{62}$

\section{Evidence-based complementary therapies}

Incontinent women who do not find conventional treatments acceptable often explore the use of complementary therapies for UI, and as adjuncts to conventional treatments. Acupuncture and moxibustion, ${ }^{63,64}$ hypnosis, ${ }^{65,66}$ yoga $^{67}$ and herbal medicines such as ginsenoside $\mathrm{Rh} 2^{68}$ are most of the complementary therapies used for UI. These therapies have shown satisfaction in UI treatment. Symptomatic improvement has been reported, women with UI were even "successfully" treated. ${ }^{66}$

\section{Alternative conservative management options}

Alternatively, there are few options used in UI management in order to collect or contain leakage (absorbent products, urinals and toileting aids, catheters) and to prevent leakage (e.g. Contrelle $\AA$ continence tampon, contiform $\AA$ and urethral plug). ${ }^{69-71}$ Scientific evidence showed that the majority of users reported improvement or cure after 3-5 weeks of treatment (up to 1 year study). ${ }^{69}$

\section{PHARMACOTHERAPY}

More than 50 million people are affected by UI worldwide and many drugs have been clinically used for the treatment of different types of UI. Although drugs may be efficacious in some patients, side-effects mean they are often discontinued after short periods of time and they are best used as an adjuvant to conservative and surgical therapy. ${ }^{8}$

\section{Antimuscarinic drugs}

Most anticholinergic drugs are antimuscarinics. They are often used to treat overactive bladder (OAB). They block muscarinic receptors in the bladder, which reduces the ability of the bladder muscle to contract and affects bladder sensation, reducing urinary urgency and the related symptoms of urgency incontinence, frequency and nocturia. The drugs differ in their selectivity for various muscarinic receptors, and some drugs have additional actions, such as direct smooth muscle effects. Antimuscarinic drugs are available in Immediate-release (I.R); Extended-Release (E.R), Long acting and transdermal formulations. Recent large meta-analyses of the most widely used antimuscarinic drugs have clearly shown these drugs provide a significant clinical benefit. $^{10,11}$

More research is needed to decide the best drugs for first, second-, or third-line treatment as none of the commonly used antimuscarinic drugs (darifenacin, fesoterodine, oxybutynin, propiverine, solifenacin, tolterodine and trospium) is an ideal first-line treatment for all OAB/DO patients. Therefore, optimal treatment should be individualised, considering the patient's comorbidities, concomitant medications and the pharmacological profiles of the different drugs. ${ }^{11,72}$

\section{Drugs with mixed actions}

Various drugs with mixed actions have been clinically used for the treatment of different types of UI. Oxybutynin, propiverine, diclyclomine, flavoxate are the more common drugs of this category. With its mixed action antimuscarinic activity, antispasmodic, anesthetic and antihistamine effects, Oxybutynin is available in IR and ER formulations. Its clinical evidence suggested increased continence rate and improved UI. ${ }^{73}$ The use of oxybutynin topical gel has been investigated in a large North American multicentre randomised, placebocontrolled study of 789 patients with OAB. ${ }^{74}$ Overall oxybutynin gel was associated with a significant decrease in urge incontinence episodes and urinary frequency when compared to placebo with a corresponding increase in voided volume. Propiverine hydrochloride is an antimuscarinic with $\mathrm{Ca}^{2+}$ channel antagonism activity. It is also recommended in pediatric patients with idiopathic or neurogenic detrusor overactivity at doses of $0.8 \mathrm{mg} / \mathrm{kg}$ body weight/day. ${ }^{75}$ Duloxetine (Yentreve $®$ ) is a potent serotonin/noradrenaline reuptake inhibitor (SNRI), approved by the European Medicines Agency (EMA) in 2004, and represents a major therapeutic advance for the treatment of SUI. ${ }^{76}$ Clinical trials showed that duloxetine; at the recommended dose of $40 \mathrm{mg}$ b.i.d. for 4 weeks, further increased to $60 \mathrm{mg}$ b.i.d. for 8 weeks, improves voiding episodes and quality of life. ${ }^{77}$

\section{$\alpha$-Adrenergic antagonists}

$\alpha$-Adrenergic antagonists (or a-blockers), increase urethral sphincter tone. Alfuzosin, doxazosin, prazosin, terazosin and tamsulosin represent the common drugs with Tamsulosin as the best studied compounds for the treatment of OAB/UUI. However, terazosin has successfully treated voiding symptoms in women with functional outflow obstruction, or Lower Urinary Tract Symptoms (LUTS). ${ }^{78,79}$

\section{$\beta$-Adroneceptors agonists}

Various studies have been investigating $\beta$-Adroneceptors agonists (especially $\beta 3$-AR agonists) as valid alternative to treat $\mathrm{OAB}$ by increasing bladder capacity with no change in micturition pressure and residual volume. Mirabegron, a $\beta 3$-adrenoceptor agonist approved by the 
EMA in 2012 for OAB, can relax detrusor smooth muscle during filling by activating $\beta 3$-ARs with a consequent increase of bladder capacity. ${ }^{80}$ With its good safety/efficacy profile, mirabegron might be a convenient therapy for $\mathrm{OAB}$ in elderly people with cognitive deficit because it is well tolerated and reduces at the same time the number of incontinence episodes and mean micturition frequency. ${ }^{80}$ It was even suggested as secondline treatment for $\mathrm{OAB}$ in patients who are poor responders or intolerant to anticholinergics. ${ }^{81}$

\section{Neurotoxin}

The injection of Botulinum (Botox $®$ ) to treat urinary incontinence in patients with neurological conditions suffering from OAB was approved by the Food and Drug Administration (FDA) in 2011, even though this treatment is not licensed for this condition by the EMA. However, in the same year, it was approved in 12 European countries for UI in adults with DO resulting from neurogenic bladder. ${ }^{82,83}$ Two clinical studies investigating the efficacy and safety of Botox in patients with Parkinson's disease (PD) and assessing the risks and benefits of longterm use for OAB/UUI have just been recently completed, the findings are yet to be published. ${ }^{84,85}$

\section{Vanilloid receptors agonists}

Vanilloid receptors are present on afferent sensory neurons innervating the detrusor and urethra. Capsaicin and Resiniferatoxin (RTX) are two drugs of this category. While the first suppresses involuntary detrusor contraction following chronic spinal cord lesion above the sacral segments, the second leads to a rapid improvement or disappearance of UI in up to $80 \%$ of selected patients and a $30 \%$ decrease in their daily urinary frequency. ${ }^{86}$

\section{Hormonal treatment}

Oestrogen treatment for UI can be given orally, vaginally or even intravesically. Oestrogen preparations have been used for many years in the treatment of urinary incontinence, however, oestrogen treatment, either alone or combined with progestogen, has achieved only poor results in UI. ${ }^{87}$ From a review of 8 controlled and 14 uncontrolled prospective trials, it was concluded that oestrogen therapy was not an efficacious treatment for stress incontinence but may be useful for symptoms of urgency and frequency. ${ }^{88}$

Desmopressin (DDVAP) is a synthetic analogue of vasopressin (also known as antidiuretic hormone), which increases water re-absorption in the renal collecting ducts without increasing blood pressure. It can be taken orally, nasally or by injection. Desmopressin has been used primarily in the treatment of nocturia and nocturnal enuresis in children ${ }^{89}$ and adults. ${ }^{90}$ More recently nasal desmopressin has been reported as a 'designer drug' for the treatment of daytime urinary incontinence..$^{91}$ Desmopressin is safe for long term use; however the drug should be used with care in the elderly due to the risk of hyponatraemia. ${ }^{12}$

\section{RESEARCH IN INCONTINENCE}

Urinary incontinence, a common and distressing condition among women, remains an issue medical, social and hygienic issue. Population studies estimate that $20-30 \%$ of women are affected but only $7-12 \%$ perceive it as a problem ${ }^{92}$ having a significant effect on quality of life (QoL). There is still a lot to be done to tackle this situation, especially in the developing countries. Basic research, epidemiology and clinical research including socioeconomic studies are the main areas where recommendations were made. For pharmacotherapy, most recently, a new area has emerged investigating the potential role of stem cells in the treatment of urinary incontinence. ${ }^{93}$ Stem cells are classically thought to aid in tissue repair via their ability for multilineage differentiation and self-renewal. They may also exert a therapeutic effect via the secretion of bioactive factors that direct other stem and progenitor cells to the area of injury, and that also possess antiapoptotic, antiscarring, neovascularization, and immunomodulatory properties. ${ }^{94}$ Their potentiality to restore function vias direct effects on the underlying mechanisms leading to incontinence or voiding dysfunction has been evaluated in preclinical animal models and clinical trials, especially for SUI. ${ }^{95-97}$

Mesenchymal Stem Cells (MSCs), Muscle-Derived Stem Cells (MDSCs), Adipose-Derived Stem Cells (ADSCs) and Urine-Derived Stem Cells (USCs) are the sources of stem cells investigated for therapeutic benefit in urologic applications. ${ }^{95,97-99}$ Clinical trials reported improvement in SUI, through great reduction in pad weight, diaryreported leaks and even a complete achievement of continence in women, with no serious adverse events (pain, bruising at biopsy or injection sites). ${ }^{95}$

To date, stem cells have shown promising results for the treatment of voiding dysfunction. Applications in SUI and $\mathrm{OAB}$ have demonstrated success in both preclinical animal trials and limited clinical trials. This research area needs to be further well investigated in order to bring a hope to the millions of women suffering from UI, and whom pharmacotherapy remains the ideal option.

\section{CONCLUSION}

Urinary continence in the female is a medical condition maintained by a series of complex mechanisms, which allow the pressure in the urethra to exceed that in a receptive bladder. Clinical evidences have shown that UI reduces both social interactions and physical activities, decreases quality of life. Associated with stigma and shame, UI women become in long term isolated from the communities, affecting the possibility to seek and to engage into treatment. Nowadays, there are various 
management and treatments methods. For women who cannot afford or tolerate surgical therapies, varieties of conservative treatments and pharmacotherapies are very much available. To date, clinical data have shown the significant benefits of these therapies. Recently, potential and promising areas have been arising in pharmacotherapy, giving alternative options to women seeking non-surgical treatment. However, with few controversial data, further well designed studies with high quality are required to tackle this problem.

\section{Abbreviations}

ADL: Activities of daily living; ADSCs: Adipose-derived stem cells; BMI: Body mass index; BUN: Blood urea nitrogen; CNS: Central nervous system; DOI: Detrusor overactivity incontinence; EMA: European medicines agency; EPI: Estimated percent improvement; ER: extended release; FDA: Food and drug administration; ICS: International continence society; IR: Immediate release; ISI: Incontinence stress index; LSA: Life space assessment; LUTS: Lower urinary tract symptoms; MDSCs: Muscle-derived stem cells; MSCs: Mesenchymal stem cells; MUI: Mixed urinary incontinence; OAB: Overactive bladder; OCD: Obsessive-compulsive disorder; PD: Parkinson's disease; PFMT: Pelvic floor muscle training; PSQ: Patient satisfaction question; PUI: Phantom urinary incontinence; PVR: Post-void residual; QoL: Quality of life; RUIS: Revised urinary incontinence scale; SUI: Stress urinary incontinence; UDI-6: Urogenital distress inventory; UI: Urinary incontinence; UTI: Urinary tract infection; USCs: Urine-derived stem cells; USI: Urodynamic stress incontinence; UUI: Urge urinary incontinence; WHO: World Health Organization.

Funding: No funding sources

Conflict of interest: None declared

Ethical approval: Not required

\section{REFERENCES}

1. Niang L, Kane R, Ndoye M, Jalloh M, Labou I, Diaw JJ, et al. Urinary incontinence in woman: Epidemiologic profile in Sub Saharian countries. Prog Urol. 2010;20(3):1213-6.

2. Hsieh CH, Su TH, Chang ST, Lin SH, Lee MC, Lee MY. Prevalence of and attitude toward urinary incontinence in postmenopausal women. Int $\mathbf{J}$ Gynaecol Obstet. 2008;100(2):171-4.

3. Rebassa M, Taltavull J, Gutiérrez C, Ripoll J, Esteva A, Miralles $\mathrm{J}$, et al. Urinary incontinence in Mallorcan women: prevalence and quality of life. Actas Urol Esp. 2013;37(6):354-61.

4. Kinchen KS, Burgio K, Diokno AC, Fultz NH, Bump R, Obenchain R. Factors associated with women's decisions to seek treatment for urinary incontinence. J Women's Health (Larchmt). 2003;12(7):687-98.
5. Wang C, Li J, Wan X, Wang X, Kane RL, Wang K. Effects of stigma on Chinese women's attitudes towards seeking treatment for urinary incontinence. J Clin Nurs. 2015 Apr;24(7-8):1112-21.

6. Abrams P, Andersson KE, Birder L, Brubaker L, Cardozo L, Chapple C, et al. Fourth International Consultation on Incontinence Recommendations of the International Scientific Committee: evaluation and treatment of urinary incontinence, pelvic organ prolapse, and fecal incontinence. Neurourol Urodyn. 2010;29(1):213-40.

7. National Collaborating Centre for Women's and Children's Health. Urinary incontinence in women: the management of urinary incontinence in women. In: RCOG, eds. A Report. London, UK: The Royal College of Obstetricians and Gynaecologists; 2013: 1-385.

8. Andersson K-E, Chapple CR, Cardozo L, Cruz F, Hashim H, Michel MC, et al. Pharmacological treatment of urinary incontinence. In: Abrams P, Khoury S, Wein A, eds. Incontinence. 3rd International Consultation on Incontinence. Plymouth, UK: Plymouth, Plymbridge Distributors Ltd; 2005: 1-811.

9. Herbison P, Hay-Smith J, Ellis G, Moore K. Effectiveness of anticholinergic drugs compared with placebo in the treatment of overactive bladder: systematic review. Br Med J. 2003;326(7394):841-4.

10. Chapple CR, Martinez-Garcia R, Selvaggi L, ToozsHobson P, Warnack W, Drogendijk T, et al. A comparison of the efficacy and tolerability of solifenacin succinate and extended release tolterodine at treating overactive bladder syndrome: results of the STAR trial. Eur Urol. 2005;48(3):46470 .

11. Novara G, Galfano A, Secco S, D'Elia C, Cavalleri $\mathrm{S}$, Ficarra V, et al. Systematic review and metaanalysis of randomized controlled trials with antimuscarinic drugs for overactive bladder. Eur Urol. 2008;54(4):740-63.

12. Schröder A, Abrams P, Andersson K-E, Artibani W, Chapple CR, Drake MJ, et al. Guideline on urinary incontinence. In: Schröder A, Abrams P, Andersson K-E, Artibani W, Chapple CR, Drake MJ, et al., eds. A Guideline. Europe: European Association of Urology; 2009: 1-52.

13. Carls C. The prevalence of stress urinary incontinence in high school and college-age female athletes in the midwest: implications for education and prevention. Urol Nurs. 2007;27(1):21-4, 39.

14. Kinchen KS, Lee J, Fireman B, Hunkeler E, Nehemiah JL, Curtice TG. The prevalence, burden, and treatment of urinary incontinence among women in a managed care plan. J Women's Health (Larchmt). 2007;16(3):415-22.

15. Sampselle CM, Harlow SD, Skurnick J, Brubaker L, Bondarenko I. Urinary incontinence predictors and life impact in ethnically diverse perimenopausal women. Obstet Gynecol. 2002;100(6):1230-8. 
16. Griffiths AN, Makam A, Edwards GJ. Should we actively screen for urinary and anal incontinence in the general gynaecology outpatients setting? - a prospective observational study. J Obstet Gynaecol. 2006;26(5):442-4.

17. Qaseem A, Dallas P, Forciea MA, Starkey M, Denberg TD, Shekelle P. Nonsurgical management of urinary incontinence in women: a clinical practice guideline from the American college of physicians. Ann Intern Med. 2014;161(6):429-40.

18. Parsons M, Cardozo L. The classification of urinary incontinence. Rev Gynaecol Pract. 2003;3(2):57-64.

19. Apell RA, Baum N. Evaluation of urinary incontinence in the elderly. J La State Med Soc. 1992;144:517-22.

20. Resnick NM, Ouslander JG. National institutes of health consensus development conference on urinary incontinence. J Am Geriatr Soc. 1990;38:263-86.

21. Resnick NM. Voiding dysfunction in the elderly. In: Yalla SV, McGuire EJ, Elbadawi A, Blaivas JG, eds. Neurology and Urodynamics: Principles and Practice. New York: Macmillan; 1988: 303-330.

22. Arlen AM, Dewhurst LL, Kirsch SS, Dingle AD, Scherz HC, Kirsch AJ. Phantom urinary incontinence in children with bladder-bowel dysfunction. Urology. 2014;84(3):685-8.

23. Minassian VA, Drutz HP, Al-Badr A. Urinary incontinence as a worldwide problem. Int J Gynecol Obstet. 2003;82(3):327-38.

24. Norton P, Brubaker L. Urinary incontinence in women. Lancet. 2006;367(9504):57-67.

25. Allen C, Kean D. Pathophysiology of urinary incontinence. Rev Gyneacol Pract. 2005;5(1):65-70.

26. Wood LN, Anger JT. Urinary incontinence in woman. BMJ. 2014;349:g4531.

27. Frullani Y. L'incontinence urinaire chez le sujet âgé. Actualités Pharmaceutiques. 2014;53(553):27-31.

28. Huebner M, Antolic A, Tunn R. The impact of pregnancy and vaginal delivery on urinary incontinence. Int J Gynecol Obstet. 2010;110(3):24951.

29. Arrue M, Diez-Itza I, Ibañez L, Paredes J, Murgiondo A, Sarasqueta C. Factors involved in the persistence of stress urinary incontinence from pregnancy to 2 years post-partum. Int $\mathbf{J}$ Gynecol Obstet. 2011;115(3):256-9.

30. McKinnie V, Swift SE, Wang W, Woodman P, O'Boyle A, Kahn M, et al. The effect of pregnancy and mode of delivery on the prevalence of urinary and fecal incontinence. Am J Obstet Gynecol. 2005;193(2):512-7

31. Lewicky-Gaupp C, Cao DC, Culbertson S. Urinary and anal incontinence in African American Teenaged Gravidas during Pregnancy and the Puerperium. J Pediatric Adolesc Gynecol. 2008;21(1):21-6.

32. Meyer S, Schreyer A, DeGrandi P, Hohfeld P. The effects of birth on urinary continence mechanisms and other pelvic-floor characteristics. Obstet Gynecol. 1998;92(4 Pt):613-8.
33. Goldberg RP, Kwon C, Gandhi S, Atkuru LV, Sorensen M, Sand PK. Urinary incontinence among mothers of multiples: the protective effect of cesarean delivery. Am J Obstet Gynecol. 2003;188(6):1447-53.

34. Wang JC, Yuan Miao, Liu GL, Feng H, Rong FN. Effects of pregnancy and childbirth on female pelvic support floor. J Shandong Univ (Health Sci). 2012;50(12):82-6.

35. Mallett VT, Brubaker L, Stoddard AM, BorelloFrance D, Tennstedt S, Hall L, et al. The expectations of patients who undergo surgery for stress incontinence. Am J Obstet Gynecol. 2008;198(3):308.e1-6.

36. Wesnes SL, Hunskaar S, Bo K, Rortveit G. Urinary incontinence and weight change during pregnancy and postpartum: a cohort study. Am J Epidemiol. 2010;172(9):1034-44.

37. Yang X, Zhang HX, Yu HY, Gao XL, Yang HX, Dong Y. The prevalence of fecal incontinence and urinary incontinence in primiparous postpartum Chinese women. Eur J Obstet Gynecol Reprod Biol. 2010;152(2):214-7.

38. Hernández RV, Aranda ER, Aznar CT. Urinary incontinence and weight changes during pregnancy and post-partum: a pending challenge. Midwifery. 2013;29(12)e123-9.

39. Mselle LT, Moland KM, Evjen-Olsen B, Mvungi A, Kohi TW. "I am nothing": experiences of loss among women suffering from severe birth injuries in Tanzania. BMC Women's Health. 2011;11:49.

40. Lee RA, Symmonds RE, Williams TJ. Current status of genitourinary fistula. Obstet Gynecol. 1988;72(3 Pt 1):313-9.

41. Eilber KS, Kavaler E, Rodriguez LV, Rosenblum N, Raz S. Ten-year experience with transvaginal vesicovaginal fistula repair using tissue interposition. J Urol. 2003;169(3):1033-6.

42. Raassen TJIP, Verdaasdonk EGG, Vierhout ME. Prospective results after first-time surgery for obstetric fistulas in East African women. Int Urogynecol J. 2008;19:73-9.

43. Miller S, Lester F, Webster M, Cowan B. Obstetric fistula: a preventable tragedy. J Midwifery Women's Health. 2005;50(4):286-94.

44. Wall LL. Obstetric vesicovaginal fistula as an international public-health problem. Lancet. 2006;368(9542):1201-9.

45. de Bernis L. Obstetric fistula: guiding principles for clinical management and programme development, a new WHO guideline. Int $\mathrm{J}$ Gynaecol Obstet. 2007;99(Suppl 1):S117-21.

46. Harrison KA. Obstetric fistula: one social calamity too many. Br J Obstet Gynaecol. 1983;90(5):385-6.

47. De Ridder D, Badlani GH, Browning A, Singh P, Sombie I, Wall LL. Fistulas in the developing world. In: Abrams P, Cardozo L, Khoury S, Wein A, eds. Incontinence. 4th ed. Paris: Health Publications; 2009: 1419-1458. 
48. Brian Hancock. Obstetric fistulae: cause and nature; the obstetric fistula complex; classification. In: Andrew Bowning, eds. Practical Fistula Surgery. 1st ed. London, UK: Paula and David Bloomer; 2005: 113.

49. Wheeler II TL, Illston JD, Markland AD, Goode PS, Richter HE. Life space assessment in older women undergoing non-surgical treatment for urinary incontinence. Open J Obstet Gynecol. 2014;4(14):809-16.

50. Chapple CR, Manassero Francesca. Urinary incontinence in adults. Surg (Oxford) Renal Urogol. 2005;23(1):101-7.

51. Paul Abrams (Scientific Committee of the First International Consultation on Incontinence). Assessment and treatment of urinary incontinence. Lancet. 2000;355:2153-8.

52. Spence-Jones C, Kamm MA, Henry MM, Hudson CN. Bowel dysfunction: a pathogenic factor in uterovaginal prolapse and urinary stress incontinence. $\mathrm{Br} \quad \mathrm{J}$ Obstet Gynaecol. 1994;101(2):147-52.

53. James JE, Sawczuk D, Merrett S. The effect of chronic caffeine consumption on urinary incontinence in psychogeriatric inpatients. Psychol Health. 1989;3(4):297-305.

54. Hannestad YS, Rortveit G, Daltveit AK, Hunskaar S. Are smoking and other lifestyle factors associated with female urinary incontinence? The Norwegian EPINCONT Study. BJOG. 2003;110(3):247-54.

55. Eliasson K, Nordlander I, Larson B, Hammarström $\mathrm{M}$, Mattson E. Influence of physical activity on urinary leakage in primiparous women. Scand J Med Sci Sports. 2005;15(2):87-94.

56. Ghaderi F, Oskouei AE. Physiotherapy for women with stress urinary incontinence: a review article. J Phys Ther Sci. 2014;26(9):1493-9.

57. Goode PS, Burgio KL, Johnson TM 2nd, Clay OJ, Roth DL, Markland AD, et al. Behavioral therapy with or without biofeedback and pelvic floor electrical stimulation for persistent postprostatectomy incontinence. JAMA. 2011;305(2):151-9.

58. Peters KM, Carrico DJ, Perez-Marrero RA, Khan AU, Wooldridge LS, Davis GL, et al. Randomized trial of percutaneous tibial nerve stimulation versus $s$ efficacy in the treatment of overactive bladder syndrome: results from the SUmiT trial. J Urol. 2010;183(4):1438-43.

59. Fujishiro T, Enomoto H, Ugawa Y, Takahashi S, Ueno S, Kitamura T. Magnetic stimulation of the sacral roots for the treatment of stress incontinence: an investigational study and placebo controlled trial. J Urol. 2000;164(4):1277-9.

60. Hasan ST, Robson WA, Pridie AK, Neal DE. Transcutaneous electrical nerve stimulation and temporary S3 neuromodulation in idiopathic detrusor instability. J Urol. 1996;155(6):2005-11.

61. Laycock J, Brown J, Cusack C, Green S, Jerwood D, Mann K, et al. Pelvic floor reeducation for stress incontinence: comparing three methods. $\mathrm{Br} \mathrm{J}$ Community Nurs. 2001;6(5):230-7.

62. Wyman JF, Fantl JA, McClish DK, Bump RC. Comparative efficacy of behavioral interventions in the management of female urinary incontinence. Continence Program for Women Research Group. Am J Obstet Gynecol. 1998;179(4):999-1007.

63. Zheng H, Sun Y, Xu Z, Hou M. Flow dynamics of urine in female patients with stress urinary incontinence treated by acupuncture and moxibustion. Int J Clin Acupuncture. 1992;3(3):2437.

64. Wang LP, Wang LC, Shi GX, Zeng L, Yang Y, Zhang $\mathrm{T}$, et al. Efficacy and safety of ginger-saltindirect moxibustion for urge urinary incontinence after stroke: protocol for a pilot multicentre randomized controlled trial. BMJ Open. 2014;4:e006326.

65. Smith N, D'Hooghe V, Duffin S, Fitzsimmons D, Rippin C, Wilde G. Hypnotherapy for the unstable bladder: four case reports. Contemp Hypnosis. 1999;16(2):87-94.

66. Diment AD. Hypnosis in the treatment of urinary incontinence. Aust $\mathrm{J}$ Clin Exp Hypnosis. 1980;8(1):13-20.

67. Vinchurkar SA, Arankalle DV. Integrating Yoga therapy in the management of urinary incontinence: a case report. J Evid Based Complement Altern Med. 2014 Dec;24:pii: 2156587214563311.

68. Chen YH, Lin YN, Chen WC, Hsieh WT, Chen HY. Treatment of stress urinary incontinence by ginsenoside Rh2. Am J Chin Med. 2014;42(4):81731.

69. Thyssen H, Bidmead J, Lose G, Møller Bek K, Dwyer P, Cardozo L. A new intravaginal device for stress incontinence in women. BJU Int. 2001;88(9):889-92.

70. Morris AR, Moore KH. The Contiform incontinence device - efficacy and patient acceptability. Int Urogynecol J. 2003;14(6):412-7.

71. Nielsen KK, Kromann-Andersen B, Jacobsen H, Nielsen EM, Nording J, Holm HH, et al. The urethral plug: A new treatment modality for genuine urinary stress incontinence in women. J Urol. 1990;144(5):1199-202.

72. Chapple CR, Van Kerrebroeck PE, Jünemann KP, Wang JT, Brodsky M. Comparison of fesoterodine and tolterodine in patients with overactive bladder. BJU Int. 2008;102(9):1128-32.

73. Shamliyan T, Wyman JF, Ramakrishnan R, Sainfort F, Kane RL. Benefits and harms of pharmacologic treatment for urinary incontinence in women: a systematic review. Ann Intern Med. 2012;156(12):861-74. W301-10.

74. Staskin DR, Dmochowski RR, Sand PK, Macdiarmid SA, Caramelli KE, Thomas E, et al. Efficacy and safety of oxybutynin chloride topical gel for overactive bladder: a randomised, double blind, placebo controlled, multicentre study. J Urol. 2009;181(4):1764-72. 
75. Marschall-Kehrel D, Feustel C, Persson de Geeter C, Stehr M, Radmayr C, Sillén U, et al. Treatment with propiverine in children suffering from nonneurogenic overactive bladder and urinary incontinence: results of a randomized placebocontrolled phase 3 clinical trial. Eur Urol. 2009;55(3):729-36.

76. Lucas MG, Bosch RJ, Burkhard FC, Cruz F, Madden TB, Nambiark AK, et al. EAU guidelines on assessment and nonsurgical management of urinary incontinence. Eur Urol. 2012;62(6):1130-42.

77. Steers WD, Herschorn S, Kreder KJ, Moore K, Strohbehn K, Yalcin I, et al. Duloxetine compared with placebo for treating women with symptoms of overactive bladder. BJU Int. 2007;100(2):337-45.

78. Kessler TM, Studer UE, Burkhard FC. The effect of terazosin on functional bladder outlet obstruction in women: a pilot study. J Urol. 2006;176(4 Pt 1):148792.

79. Low BY, Liong ML, Yuen KH, Chee C, Leong WS, Chong WL, et al. Terazosin therapy for patients with female lower urinary tract symptoms: a randomized, double-blind, placebo controlled trial. J Urol. 2008;179(4):1461-9.

80. Sanford M. Mirabegron: a review of its use in patients with overactive bladder syndrome. Drugs. 2013;73(11):1213-25.

81. Caremel R, Loutochin O, Corcos J. What do we know and not know about mirabegron, a novel b3 agonist, in the treatment of overactive bladder? Int Urogynecol J. 2014;24(2):165-70.

82. Tincello DG, Kenyon S, Abrams KR, Mayne C, Toozs-Hobson P, Taylor D, et al. Botulinum toxin a versus placebo for refractory detrusor overactivity in women: a randomised blinded placebo-controlled trial of 240 women (the RELAX study). Eur Urol. 2012; 62(3):507-14.

83. Cui Y, Wang L, Liu L, Zeng F, Niu J, Qi L, et al. Botulinum toxin-A injections for idiopathic overactive bladder: a systematic review and metaanalysis. Urol Int. 2013;91(4):429-38.

84. Anderson RU. Safety and efficacy of botulinumA toxin (BotoxA) for treatment of neurogenic bladder of Parkinson's disease. Clinical Trials, 2011. [Identifier: NCT01421719]. Available at: https://clinicaltrials.gov/ct2/show/NCT01421719.

85. Clinical Trials. Allergan long term follow-up study of safety and efficacy of botulinum toxin type A for the treatment of patients with idiopathic overactive bladder with urinary incontinence. Clinical Trialsm 2012 [Identifier: NCT00915525]. Available at: https://clinicaltrials.gov/ct2/show/NCT00915525.

86. Andersson KE, Chapple CR, Cardozo L, Cruz F, Hashim H, Michel MC, et al. Pharmacological treatment of urinary incontinence. ICS guidelines
2009. In: 4th international consultation on incontinence. Curr Opin Urol. 2009;19(4):380-94.

87. Salmon UL, Walter RI, Gast SH. The use of oestrogen in the treatment of dysuria and incontinence in postmenopausal women. Am J Obstet Gynaecol. 1941;14:23-31.

88. Sultana CJ, Walters MD. Oestrogen and urinary incontinence in women. Maturitas. 1995;20:129-38.

89. Norgaard JP, Rillig S, Djurhuus JC. Nocturnal enuresis: an approach to treatment based on pathogenesis. J Pediatr. 1989;114(4 Pt 2):705-9.

90. Lose G, Lalos O, Freeman RM, van Kerrebroeck P; Nocturia Study Group. Efficacy of desmopressin in the treatment of nocturia: a double blind placebo controlled study in women. Am J Obstet Gynecol. 2003;189(4):1106-13.

91. Robinson D, Cardozo L, Akeson M, Hvistendahl G, Riis A, Norgaard J. Women take control; Desmopressin - a drug for daytime urinary incontinence. Neurourol Urodyn. 2002;21(4):385-6.

92. McGrother CW, Shaw C, Perry SI, Dallosso SM, Mensah FK. Epidemilogy (Europe). In: Cardozo L, Staskin D eds. Textbook of Female Urology and Urogynaecology. 3rd ed. Oxford: Isis Medical Media; 2001: 21-35.

93. Tran C, Damaser MS. The potential role of stem cells in the treatment of urinary incontinence. Ther Adv Urol. 2015;7(1):22-40.

94. Gnecchi M, Zhang Z, Ni A, Dzau V. Paracrine mechanisms in adult stem cell signaling and therapy. Circ Res. 2008;103(11):1204-19.

95. Carr L, Robert M, Kultgen P, Herschorn S, Birch C, Murphy M, et al. Autologous muscle derived cell therapy for stress urinary incontinence: a prospective, dose ranging study. J Urol. 2013;189(2):595-601.

96. Cruz M, Dissaranan C, Cotleur A, Kiedrowski M, Penn M, Damaser M. Pelvic organ distribution of mesenchymal stem cells injected intravenously after simulated childbirth injury in female rats. Obstet Gynecol Int. 2012;2012:612946.

97. Kuismanen K, Sartoneva R, Haimi S, Mannerström B, Tomás E, Miettinen S, et al. Autologous adipose stem cells in treatment of female stress urinary incontinence: results of a pilot study. Stem Cells Transl Med. 2014;3(8):936-41.

98. Goldman H, Sievert K, Damaser M. Will we ever use stem cells for the treatment of SUI? - ICI-RS 2011. Neurourol Urodyn. 2012;31(3):386-9.

99. Liu G, Deng C, Zhang Y. Urine derived stem cells: biological characterization and potential clinical applications. In: Turksen K, eds. Stem Cells: Current Challenges and New Directions. 11th ed. New York: Springer; 2013.

DOI: $10.18203 / 2320-1770$. ijrcog20150047

Cite this article as: Ngarambe C, Peng D. Female urinary incontinence: a systematic overview and nonsurgical treatment. Int J Reprod Contracept Obstet Gynecol 2015;4:527-39. 